\title{
The Streetlight Effect: Reappraising the Study of Addiction in Light of the Findings of Genome- wide Association Studies
}

\author{
F. Scott Hall Yu Chen Federico Resendiz-Gutierrez \\ Department of Pharmacology and Experimental Therapeutics, College of Pharmacology and Pharmacological \\ Science, University of Toledo, Toledo, $\mathrm{OH}$, USA
}

\section{Keywords}

Drug dependence · Candidate gene studies · Genome-wide association studies

\begin{abstract}
Drug dependence has long been thought to have a genetic component. Research seeking to identify the genetic basis of addiction has gone through important transitions over its history, in part based upon the emergence of new technologies, but also as the result of changing perspectives. Early research approaches were largely dictated by available technology, with technological advancements having highly transformative effects on genetic research, but the limitations of technology also affected modes of thinking about the genetic causes of disease. This review explores these transitions in thinking about the genetic causes of addiction in terms of the "streetlight effect," which is a type of observational bias whereby people search for something only where it is easiest to search. In this way, the genes that were initially studied in the field of addiction genetics were chosen because they were the most "obvious," and formed current understanding of the biological mechanisms underlying the actions of drugs of abuse and drug dependence. The problem with this emphasis is that prior to the genomic era the vast majority of genes and proteins had yet to be identi-
\end{abstract}

fied, much less studied. This review considers how these initial choices, as well as subsequent choices that were also driven by technological limitations, shaped the study of the genetic basis of drug dependence. While genome-wide approaches overcame the initial biases regarding which genes to choose to study inherent in candidate gene studies and other approaches, genome-wide approaches necessitated other assumptions. These included additive genetic causation and limited allelic heterogeneity, which both appear to be incorrect. Thus, the next stage of advancement in this field must overcome these shortcomings through approaches that allow the examination of complex interactive effects, both gene $\times$ gene and gene $\times$ environment interactions. Techniques for these sorts of studies have recently been developed and represent the next step in our understanding of the genetic basis of drug dependence.

(c) 2021 S. Karger AG, Basel

\section{Addiction Problems Past and Present}

Although the problems associated with drug addiction and drug overdose have been a major public health focus in recent years, as well as the focus of much political attention, for addiction researchers this is not a new problem. Addiction is not a phenomenon unique to our soci- karger@karger.com www.karger.com/bbe
(C) 2021 S. Karger AG, Basel 
ety, or even to modern society, as is occasionally suggested. Indeed, it is clear that there have been opioid addiction epidemics in the USA after every major war since the civil war in the mid-19th century, as well as periods where opioid misuse resulted from poor medical practice that underestimated the potential for addiction, in addition to other contributing societal, cultural, economic, and geopolitical factors [Courtwright, 1978, 2001]. Moreover, of course, many other drugs have been abused in the USA, and elsewhere, and the abuse of particular drugs waxes and wanes, in part due to changes in public perception of their danger that rise as drug use, abuse, and overdose increase, but then are quickly forgotten as the drug becomes less popular. Of course, it is also true that in each society certain drugs are treated with much more tolerance, culturally and legally, and thus present more consistent problems for a society, as alcohol has for the USA.

One of the reasons that drugs are often tolerated within a society is the simple fact that the vast majority of people who use those drugs do not develop abuse problems, even for many "hard drugs." In considering the problems associated with drug abuse and addiction it is therefore important to consider this obvious fact and turn the question around: what is different about people who develop drug use problems from those who do not? The answer to this question is far from simple, and certainly involves a complex mix of environmental and genetic influences. This review will focus largely upon the question of genetic contributions to drug addiction and abuse liability, how the role of these genetic factors has been studied, the weaknesses that were inherent in those research approaches, and how those weaknesses may now be overcome.

\section{Drug Dependence Has a Genetic Basis}

One of the first steps in science is to formalize ways of thinking about what non-scientists often view as "obviously true." One of the benefits of this formal way of thinking is the common demonstration that "common knowledge" is often false. With regard to the genetic basis of addiction, however, common beliefs based on everyday observations are largely true. These are based upon the observation that addiction tends to be observed more often in closely related individuals. Of course, closely related individuals usually share common environments as well as genetics, so that the greatest difficulty in confirming a genetic contribution in the likelihood of developing drug use problems is in separating these factors.

The Streetlight Effect
There were 3 primary types of evidence that were initially used to establish the genetic relationship for drug dependence and drug abuse liability. Family, adoption, and twin studies examining dependence and abuse for a range of substances have all supported the view that there is a substantial genetic contribution to drug dependence [Uhl et al., 1995; Tsuang et al., 1998; True et al., 1999; Kendler et al., 2000]. There is strong evidence from studies in closely related individuals (as summarized in Schuckit [1985]) for a genetic component to drug dependence liability: (1) parental alcohol use disorder (AUD; the term we would now use instead of the term "alcoholic") is observed in $31 \%$ of persons with AUD; (2) monozygotic and dizygotic twin concordance rates are 55 and $28 \%$, respectively; and (3) adoption studies show a $44 \%$ higher rate of AUD in the adopted offspring of persons with AUD compared offspring of non-affected persons. Furthermore, an examination comparing a sample of alcohol-dependent individuals and their siblings [Bierut et al., 1998] found that the siblings of alcohol-dependent probands had elevated rates of alcohol dependence $(50 \%$ for men and $25 \%$ for women) compared to non-alcoholdependent control subjects and their siblings. Similar results have been found for dependence on other drugs, including opioids, cocaine, cannabis, and/or alcohol [Merikangas et al., 1998], with an 8-fold increased risk of drug disorders observed in the family members of drug-dependent individuals. It might be suggested that environmental factors, including just exposure to particular drugs, might also play a role here, but other evidence suggests that specific heritable factors contribute not only to the liability for drug dependence overall, but also the liability to abuse particular drugs. The familial clustering of drug use problems [Kendler et al., 1997] and the increased risk associated with having a parent with drug use problems [Midanik, 1983] strongly suggest the importance of genetic factors in drug abuse and dependence. Other approaches have helped to separate the inherent problems involved in comparing closely related individuals that also have shared environments, and in particular the influence that an addicted parent can have over the behavioral and psychological development of their offspring.

Another early approach taken to try to tease out this complex web of environmental and genetic influences was to compare children who had been adopted away from their biological parents, and therefore did not share a common environment with their biological siblings. These comparisons involved examination of the concordance for drug-related phenotypes (e.g., drug dependence) between offspring and their biological and adop- 
tive parents: a greater similarity between offspring and biological parents suggests a genetic basis for the phenotype, while greater similarity between offspring and adoptive parents suggests an environmental basis of the phenotype. Studies of this type [Cadoret et al., 1986, 1995, 1996] have found strong evidence for genetic factors in drug dependence liability, but have also found evidence for environmental risk factors, including parental divorce and parental psychiatric disorders in the adoptive parents. Before considering the different magnitudes of the contributions of these genetic and environmental factors to drug dependence and abuse liability, it must first be recognized that adoption studies have certain intrinsic limitations. Notably, biological parents of adoptees, adoptive parents, and adopted children are not representative of the population as a whole. There are reasons that parents give their children up for adoption, which may be simple, such as being young, poor, and lacking social support from their families or society as a whole. Although less information is available for biological parents of adoptees than for adoptive parents [United Nations, 2009], it is clear that biological parents have an increased incidence of virtually every type of personal (and societal) problem compared to adoptive parents, including poverty, poor health, addiction, mental illness, criminality, low education, low IQ, and so forth [Kreider and Lofquist, 2014]. Many of the traits that may underlie these outcomes are also thought to have strong genetic components and might contribute to increased drug dependence in biological parents of adoptees, as well as their adopted children. Furthermore, part of what makes the contrast between biological and adoptive parents so stark is that adoptive parents are actively selected against all of those same factors and are consequently wealthier, more educated, and more intelligent than the average parent [Kreider and Lofquist, 2014]. Additionally, many adoptions do not occur at birth, so children may have negative experiences associated with their biological parents prior to adoption. Even if adopted at birth, prenatal influences could also affect later outcomes, including prenatal illicit drug exposure, which would certainly be more likely in adoptive children than the general population. An example of this is one of the current consequences of the opioid epidemic whereby large numbers of children have been left parentless as a result of opioid drug overdoses [Winstanley and Stover, 2019].

That there exists a substantial genetic component which contributes to drug dependence and drug abuse vulnerability appears to be clear. The next most important question is how much of the liability for drug depen- dence is due to genetic factors, that is, the "heritability" of that trait. Comparisons between monozygotic and dizygotic twins, who would presumably share much of the same environmental influences, have often been used to calculate heritability, although other genetic comparisons have also been used in this manner. Reviews of such comparisons, largely from twin and adoption studies, indicate that the heritability of AUD is between 0.5 and 0.6 [Schuckit, 2009; Verhulst et al., 2015], while the range for other abused substances is slightly wider, between 0.3 and 0.8 , in part depending on the substance considered [Tsuang et al., 2001; Vink et al., 2005; Agrawal and Lynskey, 2006, 2008]. Heritability estimates give some indicator that there is a genetic component for drug dependence, but the weaknesses of such approaches are often overlooked or underestimated [Benchek and Morris, 2013]. Among many issues, a primary problem is that from the outset, to make the calculations of heritability feasible, interactions between and within components are assumed to be minimal. As shall be seen, the same additive, non-interactive assumptions have been necessary for many genetic approaches. This basic assumption may not be correct and may consequently skew the perception of the causes of drug dependence.

Ultimately, the existence of a genetic component for drug abuse liability also leads to questions of its origins. In considering the persistence of drug dependence across human cultures and across time, it is clear that the genetic contributions to addiction are certainly not an aberration, although they are commonly treated this way, as if they are something that evolution has just not gotten around to eliminating. The affinity of the anthropoid lineage for alcohol has been suggested to relate in part to a highly frugivorous diet [Dudley, 2002], although this trait is something that varies substantially across the primate lineage and is certainly not characteristic of our own species. Moreover, humans clearly have the potential for dependence upon drugs acting through many other mechanisms that involve very old genetic variants. As just one example, a variant of the fatty acid amide hydrolase gene that is associated with drug dependence is estimated to be around 150,000 years old [Flanagan et al., 2006]. Moreover, many of the mechanisms that underlie drug dependence have much older evolutionary roots than that, far older than even just the mammalian lineage [van Staaden and Huber, 2018]. These roots may lie more in the common and deep evolutionary roots for motivation and its role in learning rather than for addiction per se. Nonetheless, the potential for addiction may lie in these roots. As researchers began to explore the potential genetic basis 
for addiction the initial focus was upon systems involved in motivation, although certainly that focus has broadened over time to include various aspects of motivation, behavioral control, and decision making. Ultimately, the persistence of gene variants across time indirectly implies that there is a reason for that persistence. The genetically mediated aspects of drug dependence are certainly deleterious, so they must be in some way counterbalanced by other advantageous effects also produced by those gene variants. As we come to understand the genetic basis of drug dependence this relationship should become clearer.

In any case, estimates of heritability are just a starting point in understanding the genetic contribution to drug dependence liability. Regardless of the size of the genetic contribution, demonstration of a heritable component still leaves questions as to its underlying architecture, including how many genes are involved, which genes are involved, and how heterogeneous is this genetic contribution to drug dependence liability? The demonstration of a genetic component does not constitute an understanding of how genetic factors induce their effects upon drug dependence liability, which genes are involved, or how many genes are involved.

\section{Candidate Gene Studies: Guessing Which Genes Are Important for Addiction}

Evidence that addiction and abuse liability have some degree of a genetic component led to studies attempting to specify the genes that underlie this genetic basis. Somewhat naturally, in the pre-genomic era, the choice of which genes to study was based upon a priori understanding of the mechanisms thought to underlie the reinforcing effects of drugs of abuse. Indeed, early sequencing efforts focused on particular genes for this purpose, such as the dopamine transporter (DAT or SLC6A2 [Shimada et al., 1991]) and the $\mu$-opioid receptor (MOR or OPRM1 [Wang et al., 1993]), thought to be the primarily molecular targets for major classes of addictive drugs, psychostimulants, and opioidergic drugs, respectively. Identification of DNA sequences for these genes led to efforts to identify variation in these genes that could be used for linkage and association studies, most commonly single nucleotide polymorphisms (SNPs). The cumulative findings of candidate gene studies of drug dependence have been extensively reviewed many times [Kreek et al., 2005; Gelernter and Kranzler, 2009; Jones and Comer, 2015], including reviews that focus upon particular substances
[Stickel et al., 2017; Icick et al., 2020; Thorpe et al., 2020]. Many reviews have tended to indicate that there are greater degrees of concordance between studies than have actually been observed. A previous review by one of the present authors [Hall, 2016] analyzed results of comparisons for several genes that have been widely studied for their potential relationship to drug dependence. This included the DRD2 and OPRM1 genes, for which clearly less than half of the studies in the literature have found positive associations in candidate gene studies, and this was seen despite the well-known publication bias against negative findings.

The logic behind many candidate gene studies was generally sound from the point of view of biological relevance, although this was probably considered from a rather limited point of view, focusing mostly on the most immediate actions of drugs of abuse. Nonetheless, the consequences of some polymorphisms appeared to support the logic behind such choices in candidate gene studies. For instance, the MOR A118G SNP produces an amino acid change that alters endogenous ligand binding [Bond et al., 1998], which would be expected to affect responses to opioid drugs, including drug-induced subjective effects and drug reinforcement. However, despite the "obvious" relevance of such a genetic change, that study found no significant association of this polymorphism with opioid dependence. Subsequent studies have both found [Szeto et al., 2001; Tan et al., 2003; Bart et al., 2004] and failed to find [Li et al., 2000; Franke et al., 2001; Shi et al., 2002; Crowley et al., 2003; Tan et al., 2003] significant associations for the same polymorphism. Population admixture has been suggested to be involved in positive associations with this polymorphism when they have been observed in some, though not all, cases [Kreek et al., 2005]. Other factors associated with the populations studied and other aspects of the experimental designs surely contribute to whether or not significant associations are found, although it must be considered whether this indicates that there is no true association underlying these observations, whether the effect size is very small, hindering the observation of significant associations, or whether there is substantial heterogeneity underlying these genetic effects which also impairs the ability to identify significant associations.

Although drugs of abuse differ in many of their initial acute effects, there is a convergence in many downstream effects, including those that are involved in drug reinforcement, other forms of drug learning, and adaptations to chronic drug exposure [for review, see Scofield et al., 2016; Koob, 2020; Wise and Robble, 2020]. Consequent- 
ly, research focus has also been placed upon the downstream mechanisms that may be involved in these processes, particularly those involving dopaminergic and glutamatergic systems that are directly or indirectly affected by all drugs of abuse. The genes targeted in these systems are primarily those involved in synaptic transmission, particularly receptor mechanisms, and to a large extent this focus has persisted to the present day.

Candidate-gene approaches relate variation in particular gene loci with a chosen phenotype using linkage or association techniques that examine related and unrelated individuals, respectively. A large number of studies have examined broad phenotypes, in particular the genetic propensity to develop drug dependence overall [Smith et al., 1992; Comings et al., 1994; Berrettini et al., 1997; Vandenbergh et al., 1997; Kranzler et al., 1998; Krebs et al., 1998; Gelernter et al., 1999a; Blomqvist et al., 2000; Hoehe et al., 2000; Vandenbergh et al., 2000; Luo et al., 2003; Agrawal et al., 2006; Zhang et al., 2008], or dependence upon particular types of drugs. A priori considerations dictated many of the choices in these studies, including focusing upon the immediate targets of drugs of abuse. Thus, studies of dependence on psychomotor stimulant drugs like cocaine and amphetamine focused upon genes in dopaminergic systems [Noble et al., 1993; Persico et al., 1996; Comings et al., 1999b; Gelernter et al., 1999b; Serý et al., 2001; Tsai et al., 2002; Hong et al., 2003; Liu et al., 2004; Guindalini et al., 2006], while studies of opioid dependence focused upon opioid system genes [Mayer et al., 1997; Bond et al., 1998; Comings et al., 1999a; Franke et al., 1999; Li et al., 2000; Zimprich et al., 2000; Szeto et al., 2001; Shi et al., 2002; Xu et al., 2002; Crowley et al., 2003; Tan et al., 2003; Bart et al., 2004; Yuferov et al., 2004], studies of alcohol dependence focused on GABAergic system genes [Noble et al., 1998], and studies of nicotine dependence focused upon nicotinic cholinergic system genes [Saccone et al., 2007]. As understanding of the broader circuitry underlying drug dependence developed this focus expanded beyond the initial targets of drugs of abuse, but this still focused upon a priori knowledge. Because of the focus on dopamine as an essential mediator of drug reinforcement, there was much focus on dopaminergic genes, which can be seen in studies that examined alcohol dependence [Blum et al., 1993; Sander et al., 1997b; Noble, 1998a, b; Noble et al., 1998; Gelernter et al., 1999a; Vandenbergh et al., 2000; Gorwood et al., 2003] and opioid dependence [Kotler et al., 1997; Lawford et al., 2000], among other drugs of abuse. Similarly, because opioid systems are also thought to have a broader role in drug dependence, not just in the actions of opioids, the relationship of opioid system genes to dependence on other drugs has also been a focus of investigation [Bergen et al., 1997; Franke et al., 1999; Chen et al., 2002; Ide et al., 2004; Dahl et al., 2005; Xuei et al., 2006]. Because the basic presumption here was that the genetic effects were additive, studies also began to look at combinations of genes, although again often focusing on those thought to be involved in addiction based on their known position in drug reinforcement circuitry. For example, one study looked at the additive relationship between variants in the dopamine receptor $\mathrm{D} 2$ gene (DRD2) and the GABA receptor subunit gene a 3 (GABRA3) in alcoholism [Noble et al., 1998].

In candidate gene studies, associations between allelic markers for selected genes and dependence on specific drugs of abuse is not always consistent for reasons that have been discussed. Surprisingly, this has been the case even for genes thought to be intimately involved in the immediate pharmacological mechanisms of particular abused drugs. For example, despite the supposed importance of dopamine in the effects of alcohol, Hack et al. [2011] found that out of 10 dopaminergic system genes, only DRD4 and SLC6A3 were associated with alcohol dependence, while no significant associations were found for DRD1, DRD2, DRD3, DRD5, SLC18A2, DDC, TH, or $C O M T$. Even for drugs known to interact quite directly with the dopaminergic system, such as cocaine and methamphetamine, consistent associations with allelic markers in dopaminergic genes have not been observed. In one study of 13 candidate genes, no dopaminergic genes were associated with cue reactivity in cocaine-dependent individuals [Smelson et al., 2012], including DRD1, DRD2, $D R D 3, D R D 4$, and SLC6A3. Interestingly, significant associations were found in that study between variants in the GABRA2 and OPRM genes, which code for proteins that are less directly involved in the actions of psychostimulant drugs. Similar patterns have been observed in larger studies. Of over 1,000 SNPs examined in 130 candidate genes assessed for association with heroin dependence, 17 SNPs were nominally positive, including SNPs in a number of genes associated with dopamine, serotonin, GABA, and glutamate function; however, none of the associations were significant after correction for multiple testing [Levran et al., 2009]. This has been a consistent problem, which probably reflects all of the problems that have been discussed, including small individual effects sizes and allelic heterogeneity, as well as the tendency for studies to be underpowered given those 2 facts in particular. Somewhat consistent findings have been shown for DRD2 variants in opiate dependence [Lawford 
et al., 2000; Li et al., 2002; Clarke et al., 2014], although it has been suggested that some DRD2 associations may in fact involve adjacent genes [see discussion in Gorwood et al. 2012]. As will be discussed in the context of genomewide association studies (GWAS), the absence of implication of genes encoding proteins that are central to the immediate neural actions of many drugs of abuse may indicate that those genes may not tolerate as much variability as other genes, or, simply, that other genes are more important contributors to the development of drug use disorders despite the clear involvement of those neurotransmitter systems in the pathophysiology of addiction. Indeed, as discussed below, genetically modified mouse studies have clearly identified neurotransmitter genes (among others) that play a role in the acute actions of several drugs of abuse, including cocaine, amphetamines, and opioids.

The studies mentioned so far in this review primarily looked at the very broad phenotype of liability to develop drug dependence, or perhaps dependence on a particular drug. However, drug use disorders are far from homogeneous, and like other psychiatric conditions, individuals with the same diagnosis often have a different pattern of symptoms despite some core underlying similarity. This apparent heterogeneity of symptoms and underlying causes contributed to the development of the concept of an "endophenotype" [Gottesman and Gould, 2003], the core idea being that the wider phenotype, such as drug dependence, is formed from intermediate phenotypes or sub-phenotypes, termed endophenotypes, that have a stronger relationship to specific underlying mechanisms, including genetic mechanisms. To some extent, thinking along these lines led to an overall reconsideration of basis of psychiatric diagnoses using the Research Domain Criteria (RDoC) nosology [Morris and Cuthbert, 2012]. This initiative sought to reframe the basis of psychiatric nosology, recognizing both that underlying symptoms differed between individuals with the same Diagnostic and Statistical Manual (DSM) diagnosis, as well as the fact that the same symptoms could be observed in individuals with different diagnoses. This perspective has obvious connections to the concept of endophenotypes. Moreover, the other primary goal was to link psychiatric diagnoses to underlying biological mechanisms, which had never been a part of psychiatric diagnoses in any version of the DSM, even the most recent version, DSM V [American Psychiatric Association DSM-5 Task Force, 2013]. An important corollary of the RDoC approach to psychiatric nosology is that the underlying biological mechanisms, including genetic ones, may be more strongly linked to

The Streetlight Effect endophenotypes than to the all-encompassing phenotypes that comprise psychiatric diagnoses, including drug use disorders.

Prior to the development of these concepts, in part due to negative or inconsistent findings for the broad phenotype of drug dependence, the relationships between genetic variance and endophenotypes for drug dependence began to be explored. Indeed, such studies found stronger relationships between allelic variants and specific drugrelated phenotypes [Comings et al., 1994; Sander et al., 1997a; Shi et al., 2002; Gorwood et al., 2003; Ide et al., 2004] than were found for those same phenotypes and drug dependence overall. In this regard, although some people come to abuse any drug (polydrug abusers), many individuals tend to seek specific substances. This may relate to underlying mechanisms that specifically predispose individuals to abuse those drugs, which may include premorbid psychiatric conditions for which individuals essentially self-treat [for an extensive discussion of this topic in relation to nicotine dependence, see Hall et al., 2015]. Many lines of evidence support the overall idea of the role of self-medication in the development of drug dependence, but one of the simplest is that genetic associations may be specific to particular substances. For example, Comings et al. [1999b] found that variants in the dopamine $\mathrm{D} 3$ receptor (DRD3) were associated with cocaine dependence, but not dependence on several other classes of drugs, including amphetamines, opioids, and alcohol.

One of the fields that has developed alongside those discussed above is pharmacogenetics. This is most commonly applied to predicting responses to therapeutic drugs, which, like illicit drugs, vary substantially in individual responses. GWAS for the subjective effects of methamphetamine identified some overlap with results for GWAS for drug dependence [Hart et al., 2012], including the cell adhesion molecule CDH13. This is essentially similar to pharmacogenetic studies attempting to identify differences in response to therapeutic drug actions, although such differences might also result from different underlying disease mechanisms that require different therapeutic approaches. There are very few effective treatments for drug dependence, particularly for certain illicit drugs like methamphetamine [Kitanaka et al., 2016, 2019], but as therapeutic treatments for drug use disorders are developed it is quite likely that there will be both differences in underlying mechanisms among individuals, as well as differences in therapeutic responses. For those drugs of abuse for which treatments exist, variants in certain genes have been shown to be predictors of 


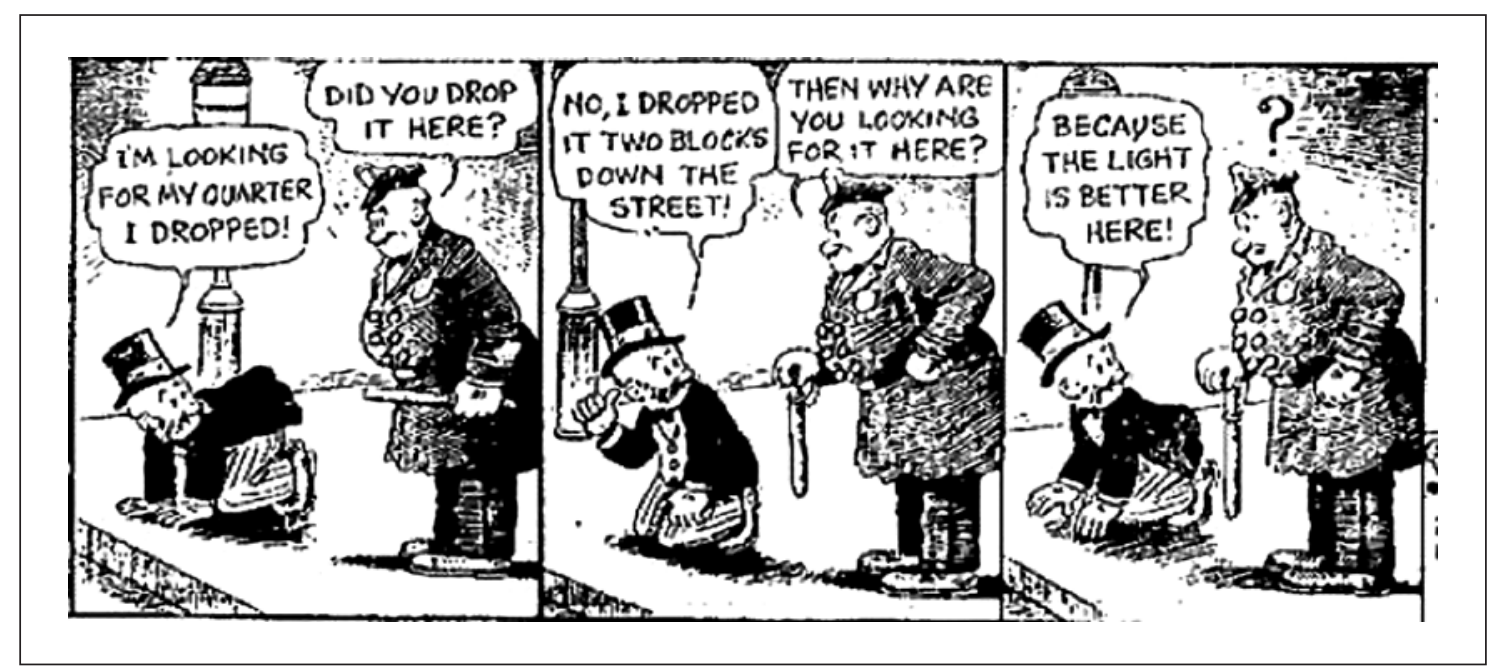

Fig. 1. Officer: “Then why are you looking for it here.” Jeff: "Because the light is better here.” Mutt and Jeff [1942].

effective treatments. For example, the effectiveness of bupropion in nicotine cessation trials is associated with variants in the dopamine $\mathrm{D} 4$ receptor (DRD4) [Leventhal et al., 2012]. In any case, these types of effects show similarly small effect sizes as those that are seen for other drug dependence phenotypes and the study of the genetics underlying therapeutic responses have similarly relied primarily upon candidate gene approaches.

Of course, there may be many reasons for inconsistencies between candidate gene studies, but the most obvious should be considered - that some positive findings are false positives. It is important to consider how these genes were chosen for study in the first place. One of the premises of this review is that these choices are based largely upon the "streetlight effect," as exemplified in this old Mutt and Jeff cartoon (Fig. 1). Like Jeff, geneticists began their search for the genetic basis of addiction based on where the light shone best; that is, those systems that were the most well-studied, for which the most tools existed, and which were most strongly linked to the acute effects of drugs of abuse. The rest of the genome was largely in the dark, in many cases only being gradually illuminated after initial discovery in the genome, with no prior understanding of their role in biology whatsoever, except based upon homology to known genes.

Thus, it seems likely that many of the findings of candidate gene studies may simply be wrong; there was great persistence in studying certain genes, even when presented with initial negative findings. After all, the proteins coded by these genes were "obviously" important for responses to addictive drugs. Conversely, other genes were simply not given consideration (they stood outside of the immediate illumination of the streetlight), or when negative findings were observed, they were accepted much more easily. The possibility that many initial findings from candidate gene studies were false positives will be reconsidered later in this review when GWAS are discussed. However, given the importance of the genes that were initially considered in candidate gene studies in the actions of drugs of abuse other possibilities should be considered. To begin with, it appears that the magnitude of the contributions of any particular gene variant to the overall genetic variation is rather small. Analysis of the magnitude of effects clearly shows this. For instance, Comings et al. [1999b] found that DRD2 and DRD3 receptor gene variants accounted for only 1.76 and $1.64 \%$ of the variance, respectively, in the liability to develop cocaine dependence. These are likely at the high end of such effect magnitudes for genetic effects in addiction, outside of some rare exceptions for alcohol dependence that involve alcohol metabolizing genes [Couzigou et al., 1994; Higuchi, 1994; Chen et al., 1999; Edenberg et al., 2019]. Another approach to capturing a larger proportion of this variance has been to examine the collective contributions of sets of gene variants to a phenotype. In one such study of cocaine dependence, Derringer et al. [2012] examined 8 dopaminergic system genes, finding that 4 SNPs in 4 of these genes accounted for $2.76 \%$ of the phenotypic variance in an initial trial sample, but only $0.54 \%$ in a subsequent test sample. If these combined effects represent the larger effects among the gene variants contributing to cocaine dependence, and the rest of the gene variants pro- 
duce even smaller additive effects, it seems likely that the total genotypic contribution involves a large number of gene variants. Moreover, this would also suggest that these smaller gene effects will be very difficult to detect consistently, which might explain the mix of positive and negative findings in the case of true positives, but also suggest that there may be many false positives in this literature as well. Additionally, this situation is likely to be exacerbated if there is substantial allelic or locus heterogeneity, or if genetic contributions to addiction involve interactive effects with other gene variants or with environmental influences on the phenotype, none of which would be apparent in a typical association study.

One of the approaches taken to potentially overcome the problem of small effect sizes, as well as the consistent problem that many candidate gene studies are statistically underpowered, is meta-analysis. In some cases, the combination of multiple studies in meta-analyses has found overall significant effects, even when there is a mix of positive and negative findings amongst the original studies. For example, Noble [1998a] combined 15 studies that examined the relationship between a $D R D 2$ receptor polymorphism and alcoholism in a meta-analysis. Of the studies included in the analysis, 8 had shown a significant association and 7 had failed to find a significant association, yet the meta-analysis found a highly significant association between DRD2 polymorphisms and drug dependence. This is not always the case though. As another example, ethnic-specific meta-analyses of the A118G $O P R M$ polymorphism found a significant overall effect in 5 studies in individuals of Asian descent, but no significant overall effect in 7 studies that examined individuals of European descent [Chen et al., 2012]. This latter study not only demonstrates the problem of potential false positives and false negatives, but also the problem that genetic background influences the outcomes of genetic studies. This is likely due to both differences in the causal variants between populations, as well as differing relationships between genetic markers and causal variants. As an example of this situation, the same haplotype variant of the neuronal cell adhesion molecule gene (NRCAM) was associated with substance abuse vulnerability in European American and African American samples, but the phase of the association was opposite in each ethnic group [Ishiguro et al., 2006].

While candidate gene approaches did establish that there is a substantial genetic component that contributes to drug dependence liability, when there has been evidence of involvement of a particular gene variant in dependence, results have been inconsistent at best. No large gene effects have been found and given the nature of the phenotypes and the effects in question it appears likely that many genetic loci are involved. However, it has been argued that many early studies were simply too underpowered, and the effect sizes too small, to consistently identify consistent results. Some meta-analyses have suggested as much. One such study found a highly significant association between DRD2 polymorphisms and drug dependence, as have others focusing on dopaminergic genes. Nonetheless, due to inconsistent findings, it has been hypothesized that allelic variants may correlate with endophenotypes, such as severity of dependence or particular symptoms. It is also possible that genetic variation primarily influences endophenotypes relevant to specific drug classes rather than a drug's action. In any case, it has been a consistent observation across these candidate gene studies that drug dependence is highly polygenic and heterogeneous.

\section{GWAS: Leaving a priori Considerations Behind}

It is clear that large gene effects are rarely found in candidate gene studies for drug dependence phenotypes. Additionally, given the magnitude of the effects, many studies have certainly been underpowered, increasing the chances of false negative findings, meaning that much of the genetic variation underlying the genetic component of predisposition to drug dependence has not been revealed by such approaches. Given that the effect of any particular genetic variant contributing to drug dependence liability is rather small, and consequently that the genetic contribution to drug dependence liability is highly polygenic, approaches examining the association of markers across the entire genome appeared to be more likely to identify a larger proportion of the gene variants contributing to drug dependence liability and other addiction-related phenotypes. The development of genome-wide approaches also resulted in fundamental change in genetic studies - a move away from a priori predictions about the nature of the genetic basis of addiction towards approaches that are not based on any preconceptions. In terms of the metaphor we have used here, this move away from a priori predictions moved beyond the range of the streetlight's illumination. To some extent this therefore became a test of the validity of those initial predictions, one which has largely shown that they were wrong, or at the very least that they vastly underestimated the complexity of the genetic causes of drug dependence. 
GWAS overcame the initial bias inherent in candidate gene approaches, but also came with a new set of problems. One of these was based upon the very large number of comparisons involved in GWAS. It was clear that such a large number of comparisons would result in an increased potential for false positive findings, but the concern for false positive results led to an increased acceptance of false negative results [for a discussion of this issue, see Sebastiani et al., 2009]. One approach to addressing this problem, one which was also more reflective of the actual scientific process, was to seek replication of the same genomic markers, or markers in the same genomic regions, in independent samples across multiple GWAS experiments. This approach identified replicable genetic influences on addiction liability, although these effects once again appeared to be highly heterogeneous, small additive effects. In many studies, nominally significant results were reported, and replication of these nominally significant results were sought across studies as a way to overcome the potential for false negative results inherent in the large number of comparisons in GWAS. This reporting of "nominal significance" was common because few studies identified any comparisons reaching the $p$ value $<10^{-8}$ significance threshold that was calculated from the large number of individual comparisons, a value commonly referred to as "genome-wide" significance. This stringency, particularly given the smaller sample sizes common in most initial GWAS, produced a bias toward type II errors. Early approaches to overcoming this initial bias included the identification of clusters of positive SNPs in individual analyses [Liu et al., 2006], as well as identification of the same chromosomal regions across multiple studies [Drgon et al., 2011], presuming that false positive results would not recur in the same regions across multiple comparisons (indeed $p$ values could be calculated for this probability as well). Using these approaches, not only were a greater number of gene variants associated with drug dependence, and a greater proportion of the genetic component identified, but the strategy also produced a greater degree of replicability. This replicability, although highly significant, was far from perfect, a reflection of both the underlying heterogeneity as well as the small effect sizes of the individual components.

One of the most important findings of these early GWAS studies was the dearth of positive findings for classical neurotransmitter system genes (e.g., receptors, transporters, etc.), many of which had been a primary focus of candidate gene studies. For example, of the 96 genes identified by clusters of positive SNPs by Liu et al. [2006], almost no monoaminergic system genes were among the significant associations. Instead, the major gene category implicated in drug dependence by this study was cell-adhesion molecules, which were $28 \%$ of the total positive associations. This study was from a series of GWAS conducted at the National Institute on Drug Abuse beginning in 2001 [Uhl et al., 2001a, b, 2007, 2008c; Liu et al., 2006; Johnson et al., 2006, 2008; Liu et al., 2006; Drgon et al., 2011]. Comparisons across these studies that involved different populations and different ethnicities identified replicable findings suggesting that the genetic basis of drug dependence liability is highly heterogeneous and highly polygenic, consisting of small additive effects [Drgon et al., 2011]. The standard of "genome-wide significance" in GWAS erred too much in favor of false negative results in its effort to avoid false positive results. Consequently, the criterion was so stringent that most GWAS could not identify any significant associations, despite clear evidence for a genetic contribution to the propensity to develop drug dependence. The alternative approach was to report "nominally significant" results at a lower statistically stringency, but then to seek replication across studies. Monte Carlo simulations examining the likelihood of repeatedly identifying the same genomic regions in multiple studies identified 50 highly replicated gene loci that were associated with drug dependence [Uhl et al., 2008a]. This list contrasts in several ways with previous candidate gene studies, including the greater number of loci identified, the higher degree of replication, and the gene classes of those genes identified. Although there was a high degree of replication, which was highly significant as determined by Monte Carlo simulations, this does not mean that the same associations were found in all studies or even that any single association was found $100 \%$ of the time. This no doubt reflects the underlying heterogeneity of drug dependence liability, consistent with previous findings in candidate gene studies. Importantly, many more associations were found, which is likely the result of consideration of genes that had been largely ignored in candidate gene studies. Although not a primary emphasis of this review, candidate gene studies have been conducted for many individual substances as well as dependence on any illicit drug. It is clear that although GWAS or candidate genes studies for dependence upon particular substances identify some substance-specific genes, the majority of the genetic contributions to substance use disorders involve general contributions to drug dependence [Kendler et al., 2003; see also discussion in Hall, 2016].

Although the prominence of cell adhesion molecule genes among those identified in GWAS studies was ini- 
tially surprising, this was reconsidered in the light of the importance of learning mechanisms in drug dependence [Uhl, 2004]. Clearly the importance of neuroplasticity and learning mechanisms in drug dependence [for a review, see Robbins et al., 2008; Badiani and Robinson, 2004 is consistent with a role of cell adhesion molecules in drug dependence mechanisms [Muskiewicz et al., 2018]. These learning mechanisms include both the development of positive reinforcement early in the course of drug dependence and negative reinforcement later in in the course of drug dependence. These mechanisms underlie important aspects of drug dependence, including drug craving and consequent drug-seeking behavior driven by drug withdrawal, stress, and drug-associated stimuli. Greater sensitivity to the development of positive and negative reinforcement in some individuals may result from changes that occur early in neurodevelopment prior to drug exposure or neuroplasticity that occurs during the course of drug exposure, but in either case could likely involve variation in genes involved in neurodevelopment and neuroplasticity, including cell adhesion molecules. The first possibility is certainly consistent with the model of behavioral endophenotypes being characteristic of drug-dependent individuals even prior to drug experiences, as well as the high degree of comorbidity of drug dependence with other psychiatric disorders that may contribute to negative reinforcement and self-medication [for a discussion of this topic, see Hall et al. 2015, 2017].

The most common gene classes that were identified in GWAS studies, including cell adhesion molecules, had not been widely considered in previous candidate gene studies, so the findings were generally novel. This clearly shows that previous candidate gene studies were limited by the streetlight effect, failing to recognize whole classes of genes that have important roles in drug dependence. Nonetheless, this does not necessarily mean that the previous candidate gene findings were erroneous for reasons previously discussed, including substantial allelic and locus heterogeneity, and stronger association with more specific drug dependence endophenotypes. For example, variation in OPRM1 has been associated with the analgesic and reinforcing effects of opioids [for a review, see Ikeda et al., 2005]. These allelic effects are highly heterogeneous; more than 100 polymorphisms in OPRM1 produce functional consequences on OPRM1 expression, binding affinity, or function. The fact that such broad variation exists within a single gene that may contribute to drug dependence phenotypes suggests 2 things: (1) once again, that many false negatives might result from examining only a small number of markers or even func- tional variants of that gene in either candidate gene studies or GWAS; and (2) that when a gene plays an important role in drug dependence it might accumulate more mutations than other genes. This is something that is certainly true for "Mendelian" disorders such as cystic fibrosis [Paranjapye et al., 2020] that are associated with a great number of potential causal genetic variants. Indeed, this genetic basis is thought to characterize such disorders. Although they are often thought of as "simple" genetic disorders, Mendelian disorders are not only associated with a great number of "causal" allelic variants within the primary gene that underlies the disorder, but also the severity of the disease differs substantially with the particular allelic variant and a number of variants in other genes that also modify the severity of the disease. The OPRM findings just mentioned may indicate that this genetic architecture that underlies Mendelian disorders is not all that different for complex diseases that have a polygenic basis.

The assumptions underlying GWAS are expressed by the Common Disease Common Variant Hypothesis [Bush and Moore, 2012], which suggests that common diseases result from genetic variation that is common in the population. The idea of small effect sizes for individual genes as well as substantial polygenetic causation naturally follow. Part of the presumption here is that GWAS will be able to identify common variants because they will occur significantly more often in the affected group compared to an unaffected control group. Heterogeneity presents a problem for identifying those variants because although a large number of individuals in the affected group might have disruption of the same genes, this might be the result of different variants in the same gene, for example allelic heterogeneity. It has now been recognized that there is far greater allelic heterogeneity in the genome overall than initially thought (or perhaps hoped for) [Hormozdiari et al., 2014, 2017]. Moreover, there is a substantial effect of sample size on the observation of allelic heterogeneity. Much higher allelic heterogeneity is observed in larger studies, suggesting that underpowered studies with smaller sample sizes have tended to give an impression that there is far less allelic heterogeneity than there actually is, although this would be an obvious explanation for the largely inconsistent results of candidate gene studies.

The identification of large numbers of associations in GWAS for common diseases did not identify the causal variants mediating those associations, only associations between marker variants. Fine mapping approaches that incorporate LD structure have been used to try to iden- 
tify the actual causal variants [Maller et al., 2012; Schaid et al., 2018]. However, most of these methods assume low allelic heterogeneity, which has been shown to be much higher than initially thought [Hormozdiari et al., 2014, 2017]. Analyses examining allelic heterogeneity have looked at genetic loci implicated in several common disorders, including psychiatric disorders. Methods for examining allelic heterogeneity have yet to be applied to drug dependence, but based upon the substantial overlap between genes associated with drug dependence and those associated with psychiatric disorders [Uhl et al., 2008b, 2010; Johnson et al., 2009], it seems likely that there will be substantial allelic heterogeneity for drug dependence as well.

If allelic heterogeneity is higher than initially thought, false negatives are likely to be an ongoing problem in GWAS for drug dependence. Of the 15 GWAS for alcohol dependence listed in the NHGRI Catalog of GWAS [Hindorff et al., 2014], only 1 identified a significant association with alcohol dehydrogenase $2(A L D H 2)$, a gene widely associated with alcohol dependence [Edenberg and Foroud, 2013]. In any case, even this very large gene effect only accounted for $17 \%$ of the genetic variance contributing to alcohol dependence. As associations with drug dependence go, this is a very large effect, but still fails to account for the majority of the variance in genetic contributions to alcohol dependence and is fully consistent with a highly polygenic and heterogeneous genetic architecture. Using the clustering strategy previously mentioned [Drgon et al., 2010], a high degree of replication across GWAS for drug dependence has been observed. Despite this potential problem of allelic heterogeneity, the analysis of multiple GWAS findings that was discussed previously [Uhl et al., 2008a] did find a high degree of replication. Certainly, each drug-dependence related gene is not identified in every study $100 \%$ of the time, but based on the considerations discussed here $100 \%$ concordance would not be expected across studies - that is, it is likely that the set of genes involved in drug dependence in different populations, in dependence on different substances, in different levels of dependence, and so forth, may not completely overlap. As this field progresses it is likely that we will be able to demonstrate different sets of genes associated with each of these modifying conditions.

By their nature, GWAS studies make no presumptions about which particular gene variants contribute to the heritable component of drug dependence liability in humans, although by necessity they do maintain the presumption of an additive model. Many of the other problems that plagued candidate gene studies persisted with
GWAS, including underpowered studies, particularly in the context of the far greater number of comparisons, and consequent debate over statistical stringency and the trade-off between type I and type II errors, that is false positives versus false negatives. Of course, one of the solutions to these problems would be very large samples sizes, not just hundreds of subjects, but tens of thousands of subjects [Visscher et al., 2017]. Such studies are a massive effort in terms of resources, and few such studies have been done. This solution alone, however, does not seem to identify more genes that were observed in previous, much smaller GWAS. For instance, one study of AUD examined over 250,000 subjects but only found 10 positive associations [Kranzler et al., 2019]. Some of the positive findings in this study replicated previous findings from candidate gene studies or smaller GWAS, but several had not been previously observed. When the data were split by ethnicity (e.g., genetic background), the findings in European Americans overlapped to a rather small extent with the findings in other ethnicities. Overall, the hope that much larger studies will identify a majority of the genetic contribution to drug dependence liability does not seem to be supported, but it is likely that any solution to this problem is likely to require much larger samples. The failure to identify more of the genetic components of drug dependence liability by just increasing the samples size may mean that one of the primary assumptions of GWAS was not true, that is additivity. It may be possible that the answers to understanding the genetic component of addiction, and other complex diseases, lies in examining interactions, either gene-gene interactions or gene-environment interactions. Before considering this issue, studies addressing the findings of GWAS studies should be addressed.

\section{Confirming that the Results of GWAS Studies Are Not Just False Positives}

Association studies, whether candidate gene studies or GWAS, establish a link between genetic markers and an outcome. The search for a causal variant is often the next logical stage of inquiry, but functional genetic studies are far less common than GWAS [Gallagher and Chen-Plotkin, 2018]. When the issue of causal variants is raised there has long been a bias towards searching for variants that cause amino acid changes, even though these types of variants are far less common than other variants. Indeed, more than $90 \%$ of disease-associated gene variants are located in non-protein coding regions [Schaub et al., 
2012], and are enriched in transcriptional regulatory elements [Maurano et al., 2012]. Consistent with these findings, a fine mapping study that followed initial positive findings in GWAS identified an NRCAM haplotype that influences NRCAM gene expression [Ishiguro et al., 2006]. The differences in gene expression resulting from the gene variants underlying these sorts of haplotypes, as well as other variants in high-linkage disequilibrium, likely contribute to changes in gene expression in a complex manner. In the same way that the between locus effects appear to be highly complex and interactive, the within locus effects are also likely to be much more complex and interactive than was initially presumed (or hoped). This situation will make the search for "functional variants" for complex diseases quite difficult and perhaps require a paradigm shift to a more probabilistic and less absolute causal conception for it to be truly understood.

Another approach taken to confirm the results of GWAS is to examine manipulations of those genes in mouse models. Just as preclinical studies were widely used as a starting point for nominating genes to be studied in candidate gene studies, they were also used to confirm the potential role of novel genes nominated by GWAS. In particular, genetically modified mice were widely used for this purpose. These studies have been widely reviewed [Charbogne et al., 2014; Uhl et al., 2014; Muskiewicz et al., 2018], so only a few points will be made on this topic here. GWAS for drug dependence nominated many novel genes for potential involvement in drug dependence phenotypes. Among the approaches taken was to examine the effects of eliminating the gene (e.g., a gene "knockout") on drug abuse-related phenotypes. This approach was in fact one of the first approaches taken in parallel with candidate gene studies prior to the genomic era. Like the genes that were studied in candidate gene studies, the main target proteins for the major drugs of abuse were of particular interest in gene knockout studies, including the main molecular targets for opioids (Oprm1), amphetamines (Vmat2), and cocaine (Slc6a3; DAT; e.g., Sora et al. [1997], Takahashi et al. [1997], and Sora et al. [1998], and for some overall summaries see Sora et al. [2010], Hall et al. [2013], and Moriya et al. [2013]). The primary goal of these initial studies, and many others that have examined the primary molecular targets for other drugs of abuse, was to determine whether gene modifications would alter behavioral responses to drugs of abuse, particularly those that were most relevant to drug dependence. In these studies, there were no real attempts to model human allelic variation using knock-in mice in which human allelic variants associated with drug dependence are inserted in place of the endogenous version of the gene. Some knock-in mice have been studied, but rather than modeling human variation these genetically modified mice were designed to either induce a hypersensitive receptor [e.g., Tapper et al., 2004] or to eliminate substrate binding [e.g., Thomsen et al., 2009]. Like the more commonly studied homozygous gene knockout mice that eliminate all expression of the target gene/protein, these knock-in approaches likely had more powerful effects than naturally occurring variants. Although not terribly illuminating with respect to naturally occurring genetic variation that might underlie the predisposition to drug dependence, these studies did identify critical proteins involved in behavioral responses to drugs of abuse, including many phenotypes that are relevant to drug dependence.

In part because of this history, the same logic was used to confirm the potential involvement of some of the novel genes implicated in drug dependence by GWAS. Again, these approaches did not seek to duplicate the sort of functional consequences of the human variants, and like the studies of candidate genes the magnitude of the changes were likely much greater than the magnitude of effects resulting from naturally occurring variation in these genes. Instead, the logic was that if these genes were important for drug dependence phenotypes then the complete elimination of gene/protein expression should affect drug dependence phenotypes. This was really intended to be more of a test for potential false positive outcomes from GWAS studies than an exploration of the mechanisms of the causal variants underlying GWAS. If genetic modifications in a small number of genes identified from all of the human genes tested in GWAS approaches, which had no previous implication in drug dependence, were found to affect drug dependence phenotypes, then this would be taken as an indication that these were true positives rather than false positives. Studies in genetically modified mice have shown that reductions in the expression of several CAM genes that were repeatedly associated with drug dependence, including NrCAM [Ishiguro et al., 2006], CDH13 [Drgonova et al., 2016], CSMD1 [Drgonova et al., 2015a], and PTPRD [Drgonova et al., 2015b; Uhl et al., 2018], affect behavioral responses to drugs of abuse and/or behavioral phenotypes relevant to addiction. Consequently, these studies strongly support the findings of GWAS that implicate variation in these genes in the predisposition to develop drug dependence. It must be remembered that these genes were identified in genome-wide approaches, and thus selected from 
the entire genome, and the likelihood of them all affecting drug dependence phenotypes by chance would be extremely low.

The identification of novel classes of genes, and the confirmation of their importance in drug dependence, may also provide some illumination of the evolutionary mechanisms that lie behind the persistence of these gene variants through time. The ability to learn about motivationally relevant stimuli, the ability to store those memories over long periods, and the resulting motivational effects of those stimuli will certainly have positive effects upon survival. Organisms that remember better or have strong induction of motivational states by conditioned stimuli might be better able to survive and reproduce. However, just as it is for other traits, enhanced memory and motivation may be a two-edged sword if certain types of stimuli gain too much control over behavior, at the expense of other organismal needs. Indeed, in recent decades this has been a common description of the propensity to develop drug dependence, as actions too quickly or too strongly lead to the development of habits and compulsions [Everitt and Robbins, 2005, 2016]. As our understanding of the totality of genetic contributions to drug dependence liability deepens in the post-GWAS era, including the nature of gene-environment interactions, so will our ability to trace the evolutionary roots of addiction.

\section{Moving Forward in the Post-GWAS Era}

This review has considered several important transitions in approaches to studying the genetic basis of addiction. In particular, this review has used the streetlight analogy to illustrate how initial attempts to understand addiction were biased by our choice of gene targets to study. GWAS overcame this initial bias but came with a separate set of problems. GWAS moved the field forward in many ways, but to continue to move the field forward it will be necessary to once again step back and consider what preconceptions continue to limit progress. One of the core assumptions that was necessary for GWAS was that the genetic effects are additive. A deeper understanding of the genetic basis of addiction will require considering gene $\times$ gene and gene $\times$ environment interactions and developing methods for doing so. Recent analytical and technical advancements are beginning to allow us to look not just at highly interactive genetic effects [Joubert et al., $2018,2019]$, but also at multiple "omic" levels simultaneously [Weighill et al., 2019]. These multiple omic levels include the genome, the epigenome, the transcriptome, and the proteome, among others. Some of the inconsistency in genetic findings from candidate gene and GWAS approaches probably results not only from allelic heterogeneity, but also from the fact that the genetic "signal" is obscured by a heterogeneous set of complex genetic and environmental interactions that should be observable in alterations at other levels, including the epigenome and transcriptome. Moreover, it has become clear that many of the underlying mechanisms mediating drug dependence liability involve changes in gene expression that are highly tissue and cell specific [Gallagher and Chen-Plotkin, 2018]. This of course means that a single transcriptome analysis will not provide a full explanation of the underlying mechanisms. In the coming years newer approaches to the study of drug dependence, and other complex diseases, will be able to specify the genetic contributions to addiction that have been missed so far by examining gene $\times$ gene and gene $\times$ environment interactions, and how they affect multiple functional levels in a cell type- and tissue-specific manner. This will allow a much clearer view of the etiology and biology of addiction, as well as identifying more critical points that can be used in the developing addiction therapeutics.

\section{Acknowledgements}

The authors thank the J.B. Johnston Club in Evolutionary Neuroscience and Karger for organizing the 31st Karger Workshop on Evolutionary Neuroscience.

\section{Conflict of Interest Statement}

The authors have no conflicts of interest to declare.

\section{Funding Sources}

This review was supported by The University Toledo.

\section{Author Contributions}

F.S.H. wrote the first draft; all authors then contributed to editing the manuscript. 


\section{References}

Agrawal A, Edenberg HJ, Foroud T, Bierut LJ, Dunne G, Hinrichs AL, et al. Association of GABRA2 with drug dependence in the collaborative study of the genetics of alcoholism sample. Behav Genet. 2006 Sep;36(5):640-50.

Agrawal A, Lynskey MT. The genetic epidemiology of cannabis use, abuse and dependence. Addiction. 2006 Jun;101(6):801-12.

Agrawal A, Lynskey MT. Are there genetic influences on addiction: evidence from family, adoption and twin studies. Addiction. 2008 Jul;103(7):1069-81.

American Psychiatric Association DSM-5 Task Force. Diagnostic and statistical manual of mental disorders: DSM-5. Washington: American Psychiatric Association; 2013.

Badiani A, Robinson TE. Drug-induced neurobehavioral plasticity: the role of environmental context. Behav Pharmacol. 2004 Sep;15(5-6): 327-39.

Bart G, Heilig M, LaForge KS, Pollak L, Leal SM, Ott J, et al. Substantial attributable risk related to a functional mu-opioid receptor gene polymorphism in association with heroin addiction in central Sweden. Mol Psychiatry. 2004 Jun;9(6):547-9.

Benchek PH, Morris NJ. How meaningful are heritability estimates of liability? Hum Genet. 2013 Dec;132(12):1351-60.

Bergen AW, Kokoszka J, Peterson R, Long JC, Virkkunen M, Linnoila M, et al. Mu opioid receptor gene variants: lack of association with alcohol dependence. Mol Psychiatry. 1997 Oct-Nov;2(6):490-4.

Berrettini WH, Hoehe MR, Ferraro TN, Demaria PA, Gottheil E. Human mu opioid receptor gene polymorphisms and vulnerability to substance abuse. Addict Biol. 1997 Jul;2(3): 303-8.

Bierut LJ, Dinwiddie SH, Begleiter H, Crowe RR, Hesselbrock V, Nurnberger JI Jr, et al. Familial transmission of substance dependence: alcohol, marijuana, cocaine, and habitual smoking: a report from the Collaborative Study on the Genetics of Alcoholism. Arch Gen Psychiatry. 1998 Nov;55(11):982-8.

Blomqvist O, Gelernter J, Kranzler HR. Familybased study of DRD2 alleles in alcohol and drug dependence. Am J Med Genet. 2000 Oct; 96(5):659-64.

Blum K, Noble EP, Sheridan PJ, Montgomery A, Ritchie T, Ozkaragoz T, et al. Genetic predisposition in alcoholism: association of the D2 dopamine receptor TaqI B1 RFLP with severe alcoholics. Alcohol. 1993 Jan-Feb;10(1):59-67.

Bond C, LaForge KS, Tian M, Melia D, Zhang S, Borg L, et al. Single-nucleotide polymorphism in the human mu opioid receptor gene alters beta-endorphin binding and activity: possible implications for opiate addiction. Proc Natl Acad Sci USA. 1998 Aug;95(16): 9608-13.

Bush WS, Moore JH. Chapter 11: genome-wide association studies. PLoS Comput Biol. 2012; 8(12):e1002822.
Cadoret RJ, Troughton E, O'Gorman TW, Heywood E. An adoption study of genetic and environmental factors in drug abuse. Arch Gen Psychiatry. 1986 Dec;43(12):1131-6.

Cadoret RJ, Yates WR, Troughton E, Woodworth G, Stewart MA. Adoption study demonstrating two genetic pathways to drug abuse. Arch Gen Psychiatry. 1995 Jan;52(1):42-52.

Cadoret RJ, Yates WR, Troughton E, Woodworth G, Stewart MA. An adoption study of drug abuse/dependency in females. Compr Psychiatry. 1996 Mar-Apr;37(2):88-94.

Charbogne P, Kieffer BL, Befort K. 15 years of genetic approaches in vivo for addiction research: Opioid receptor and peptide gene knockout in mouse models of drug abuse. Neuropharmacology. 2014 Jan;76 Pt B(0 0): 204-17.

Chen AC, LaForge KS, Ho A, McHugh PF, Kel$\operatorname{logg} \mathrm{S}$, Bell K, et al. Potentially functional polymorphism in the promoter region of prodynorphin gene may be associated with protection against cocaine dependence or abuse. Am J Med Genet. 2002 May;114(4):429-35.

Chen CC, Lu RB, Chen YC, Wang MF, Chang YC, $\mathrm{Li} \mathrm{TK}$, et al. Interaction between the functional polymorphisms of the alcohol-metabolism genes in protection against alcoholism. Am J Hum Genet. 1999 Sep;65(3):795-807.

Chen D, Liu L, Xiao Y, Peng Y, Yang C, Wang Z. Ethnic-specific meta-analyses of association between the OPRM1 A118G polymorphism and alcohol dependence among Asians and Caucasians. Drug Alcohol Depend. 2012 Jun; 123(1-3):1-6.

Clarke TK, Weiss AR, Ferarro TN, Kampman KM, Dackis CA, Pettinati HM, et al. The dopamine receptor D2 (DRD2) SNP rs1076560 is associated with opioid addiction. Ann Hum Genet. 2014 Jan;78(1):33-9.

Comings DE, Blake H, Dietz G, Gade-Andavolu R, Legro RS, Saucier G, et al. The proenkephalin gene (PENK) and opioid dependence. Neuroreport. 1999a Apr;10(5):1133-5.

Comings DE, Gonzalez N, Wu S, Saucier G, Johnson P, Verde R, et al. Homozygosity at the dopamine DRD3 receptor gene in cocaine dependence. Mol Psychiatry. 1999b Sep;4(5): 484-7.

Comings DE, Muhleman D, Ahn C, Gysin R, Flanagan $\mathrm{SD}$. The dopamine $\mathrm{D} 2$ receptor gene: a genetic risk factor in substance abuse. Drug Alcohol Depend. 1994 Feb;34(3):175-80.

Courtwright DT. Dark paradise: a history of opiate addiction in America. Cambridge: Harvard University Press; 2001.

Courtwright DT. Opiate addiction as a consequence of the Civil War. Civ War Hist. 1978; 24(2):101-11.

Couzigou P, Coutelle C, Fleury B, Iron A. Alcohol and aldehyde dehydrogenase genotypes, alcoholism and alcohol related disease. Alcohol Alcohol Suppl. 1994;2:21-7.
Crowley JJ, Oslin DW, Patkar AA, Gottheil E, DeMaria PA Jr, O'Brien CP, et al. A genetic association study of the mu opioid receptor and severe opioid dependence. Psychiatr Genet. 2003 Sep;13(3):169-73.

Dahl JP, Weller AE, Kampman KM, Oslin DW, Lohoff FW, Ferraro TN, et al. Confirmation of the association between a polymorphism in the promoter region of the prodynorphin gene and cocaine dependence. Am J Med Genet B Neuropsychiatr Genet. 2005 Nov; 139B(1):106-8

Derringer J, Krueger RF, Dick DM, Aliev F, Grucza RA, Saccone S, et al.; GENEVA consortium. The aggregate effect of dopamine genes on dependence symptoms among cocaine users: cross-validation of a candidate system scoring approach. Behav Genet. 2012 Jul; 42(4):626-35.

Drgon T, Johnson CA, Nino M, Drgonova J, Walther DM, Uhl GR. "Replicated" genome wide association for dependence on illegal substances: genomic regions identified by overlapping clusters of nominally positive SNPs. Am J Med Genet B Neuropsychiatr Genet. 2011 Mar;156(2):125-38.

Drgon T, Zhang PW, Johnson C, Walther D, Hess $\mathrm{J}$, Nino M, et al. Genome wide association for addiction: replicated results and comparisons of two analytic approaches. PLoS One. 2010 Jan;5(1):e8832.

Drgonova J, Walther D, Hartstein GL, Bukhari MO, Baumann MH, Katz J, et al. Cadherin 13: human cis-regulation and selectively-altered addiction phenotypes and cerebral cortical dopamine in knockout mice. Mol Med. 2016 Oct;22(1):537-47.

Drgonova J, Walther D, Singhal S, Johnson K, Kessler B, Troncoso J, et al. Altered CSMD1 Expression Alters Cocaine-Conditioned Place Preference: Mutual Support for a Complex Locus from Human and Mouse Models. PLoS One. 2015a Jul;10(7):e0120908.

Drgonova J, Walther D, Wang KJ, Hartstein GL, Lochte B, Troncoso J, et al. Mouse Model for Protein Tyrosine Phosphatase D ( PTPRD) Associations with Restless Leg Syndrome or Willis-Ekbom Disease and Addiction: Reduced Expression Alters Locomotion, Sleep Behaviors and Cocaine-Conditioned Place Preference. Mol Med. 2015b Nov;21(1):717-25.

Dudley R. Fermenting fruit and the historical ecology of ethanol ingestion: is alcoholism in modern humans an evolutionary hangover? Addiction. 2002 Apr;97(4):381-8.

Edenberg HJ, Foroud T. Genetics and alcoholism. Nat Rev Gastroenterol Hepatol. 2013 Aug; 10(8):487-94.

Edenberg HJ, Gelernter J, Agrawal A. Genetics of Alcoholism. Curr Psychiatry Rep. 2019 Mar; 21(4):26

Everitt BJ, Robbins TW. Neural systems of reinforcement for drug addiction: from actions to habits to compulsion. Nat Neurosci. 2005 Nov;8(11):1481-9. 
Everitt BJ, Robbins TW. Drug Addiction: Updating Actions to Habits to Compulsions Ten Years On. Annu Rev Psychol. 2016;67(1):2350.

Flanagan JM, Gerber AL, Cadet JL, Beutler E, Sipe JC. The fatty acid amide hydrolase 385 A/A (P129T) variant: haplotype analysis of an ancient missense mutation and validation of risk for drug addiction. Hum Genet. 2006 Nov; 120(4):581-8

Franke P, Nöthen MM, Wang T, Neidt H, Knapp M, Lichtermann D, et al. Human delta-opioid receptor gene and susceptibility to heroin and alcohol dependence. Am J Med Genet. 1999 Oct; $88(5): 462-4$.

Franke P, Wang T, Nöthen MM, Knapp M, Neidt $\mathrm{H}$, Albrecht S, et al. Nonreplication of association between mu-opioid-receptor gene (OPRM1) A118G polymorphism and substance dependence. Am J Med Genet. 2001 Jan;105(1):114-9.

Gallagher MD, Chen-Plotkin AS. The PostGWAS Era: From Association to Function. Am J Hum Genet. 2018 May;102(5):717-30.

Gelernter J, Kranzler HR. Genetics of alcohol dependence. Hum Genet. 2009 Jul;126(1):91-9.

Gelernter J, Kranzler H, Cubells J. Genetics of two $\mathrm{mu}$ opioid receptor gene (OPRM1) exon I polymorphisms: population studies, and allele frequencies in alcohol- and drug-dependent subjects. Mol Psychiatry. 1999a Sep;4(5): 476-83.

Gelernter J, Kranzler H, Satel SL. No association between D2 dopamine receptor (DRD2) alleles or haplotypes and cocaine dependence or severity of cocaine dependence in European- and African-Americans. Biol Psychiatry. 1999b Feb;45(3):340-5.

Gorwood P, Le Strat Y, Ramoz N, Dubertret C, Moalic JM, Simonneau M. Genetics of dopamine receptors and drug addiction. Hum Genet. 2012 Jun;131(6):803-22.

Gorwood P, Limosin F, Batel P, Hamon M, Adès $\mathrm{J}$, Boni $\mathrm{C}$. The A9 allele of the dopamine transporter gene is associated with delirium tremens and alcohol-withdrawal seizure. Biol Psychiatry. 2003 Jan;53(1):85-92.

Gottesman II, Gould TD. The endophenotype concept in psychiatry: etymology and strategic intentions. Am J Psychiatry. 2003 Apr; 160(4):636-45.

Guindalini C, Howard M, Haddley K, Laranjeira R, Collier D, Ammar N, et al. A dopamine transporter gene functional variant associated with cocaine abuse in a Brazilian sample. Proc Natl Acad Sci USA. 2006 Mar;103(12):45527.

Hack LM, Kalsi G, Aliev F, Kuo PH, Prescott CA, Patterson DG, et al. Limited associations of dopamine system genes with alcohol dependence and related traits in the Irish Affected Sib Pair Study of Alcohol Dependence (IASPSAD). Alcohol Clin Exp Res. 2011 Feb; 35(2):376-85

Hall FS. Chapter 16: Reverse translational implications of genome-wide association studies for addiction genetics. In: Preedy VR, editor.
Neuropathology of drug addictions and substance misuse. San Diego: Academic Press; 2016. pp. 153-64.

Hall FS, Der-Avakian A, Gould TJ, Markou A, Shoaib M, Young JW. Negative affective states and cognitive impairments in nicotine dependence. Neurosci Biobehav Rev. 2015 Nov; $58: 168-85$.

Hall FS, Drgonova J, Jain S, Uhl GR. Implications of genome wide association studies for addiction: are our a priori assumptions all wrong? Pharmacol Ther. 2013 Dec;140(3):267-79.

Hall FS, Young JW, Der-Avakian A. Negative affective states and cognitive impairments in nicotine dependence. Amsterdam, Boston: Elsevier/Academic Press; 2017.

Hart AB, Engelhardt BE, Wardle MC, Sokoloff G, Stephens M, de Wit H, et al. Genome-wide association study of $\mathrm{d}$-amphetamine response in healthy volunteers identifies putative associations, including cadherin 13 (CDH13). PLoS One. 2012;7(8):e42646.

Higuchi S. Polymorphisms of ethanol metabolizing enzyme genes and alcoholism. Alcohol Alcohol Suppl. 1994;2:29-34.

Hindorff L, MacArthur JEBI, Morales JEBI, Junkins $\mathrm{H}$, Hall P, Klemm A, et al. A catalog of published genome-wide association studies. 2014. Available from: www.genome.gov/gwastudies.

Hoehe MR, Köpke K, Wendel B, Rohde K, Flachmeier C, Kidd KK, et al. Sequence variability and candidate gene analysis in complex disease: association of mu opioid receptor gene variation with substance dependence. Hum Mol Genet. 2000 Nov;9(19):2895-908.

Hong CJ, Cheng CY, Shu LR, Yang CY, Tsai SJ. Association study of the dopamine and serotonin transporter genetic polymorphisms and methamphetamine abuse in Chinese males. J Neural Transm. 2003 Apr;110(4):345-51.

Hormozdiari F, Kostem E, Kang EY, Pasaniuc B, Eskin E. Identifying causal variants at loci with multiple signals of association. Genetics. 2014 Oct; 198(2):497-508.

Hormozdiari F, Zhu A, Kichaev G, Ju CJ, Segrè AV, Joo JW, et al. Widespread Allelic Heterogeneity in Complex Traits. Am J Hum Genet. 2017 May; 100(5):789-802.

Icick R, Forget B, Cloëz-Tayarani I, Pons S, Maskos U, Besson M. Genetic susceptibility to nicotine addiction: advances and shortcomings in our understanding of the CHRNA5/ A3/B4 gene cluster contribution. Neuropharmacology. 2020 Oct; 177:108234.

Ide S, Kobayashi H, Tanaka K, Ujike H, Sekine Y, Ozaki N, et al. Gene polymorphisms of the mu opioid receptor in methamphetamine abusers. Ann NY Acad Sci. 2004 Oct;1025(1):31624.

Ikeda K, Ide S, Han W, Hayashida M, Uhl GR, Sora I. How individual sensitivity to opiates can be predicted by gene analyses. Trends Pharmacol Sci. 2005 Jun;26(6):311-7.

Ishiguro $\mathrm{H}$, Liu QR, Gong JP, Hall FS, Ujike $\mathrm{H}$, Morales M, et al. NrCAM in addiction vulnerability: positional cloning, drug-regulation, haplotype-specific expression, and altered drug reward in knockout mice. Neuropsychopharmacology. 2006 Mar;31(3):572-84.

Johnson C, Drgon T, Liu QR, Walther D, Edenberg $\mathrm{H}$, Rice J, et al. Pooled association genome scanning for alcohol dependence using 104,268 SNPs: validation and use to identify alcoholism vulnerability loci in unrelated individuals from the collaborative study on the genetics of alcoholism. Am J Med Genet B Neuropsychiatr Genet. 2006 Dec;141B(8): 844-53.

Johnson C, Drgon T, Liu QR, Zhang PW, Walther $\mathrm{D}$, Li CY, et al. Genome wide association for substance dependence: convergent results from epidemiologic and research volunteer samples. BMC Med Genet. 2008 Dec;9(1): 113

Johnson C, Drgon T, McMahon FJ, Uhl GR. Convergent genome wide association results for bipolar disorder and substance dependence. Am J Med Genet B Neuropsychiatr Genet. 2009 Mar;150B(2):182-90.

Jones JD, Comer SD. A review of pharmacogenetic studies of substance-related disorders. Drug Alcohol Depend. 2015 Jul;152:1-14

Joubert W, Nance J, Climer S, Weighill D, Jacobson D. Parallel accelerated Custom Correlation Coefficient calculations for genomics applications. Parallel Computing. 2019;84:15-23.

Joubert W, Weighill D, Kainer D, Climer S, Justice A, Fagnan K, et al. Attacking the opioid epidemic: determining the epistatic and pleiotropic genetic architectures for chronic pain and opioid addiction. SC18: International Conference for High Performance Computing, Networking, Storage and Analysis, 2018. pp. 717-30.

Kendler KS, Davis CG, Kessler RC. The familial aggregation of common psychiatric and substance use disorders in the National Comorbidity Survey: a family history study. Br J Psychiatry. 1997 Jun;170(6):541-8.

Kendler KS, Jacobson KC, Prescott CA, Neale MC. Specificity of genetic and environmental risk factors for use and abuse/dependence of cannabis, cocaine, hallucinogens, sedatives, stimulants, and opiates in male twins. Am J Psychiatry. 2003 Apr;160(4):687-95.

Kendler KS, Karkowski LM, Neale MC, Prescott CA. Illicit psychoactive substance use, heavy use, abuse, and dependence in a US population-based sample of male twins. Arch Gen Psychiatry. 2000 Mar;57(3):261-9.

Kitanaka J, Kitanaka N, Hall FS, Uhl GR, Takemura M. Brain Histamine N-Methyltransferase As a Possible Target of Treatment for Methamphetamine Overdose. Drug Target Insights. 2016 Mar; 10:1-7.

Kitanaka N, Hall FS, Uhl GR, Kitanaka J. Lithium Pharmacology and a Potential Role of Lithium on Methamphetamine Abuse and Dependence. Curr Drug Res Rev. 2019;11(2):85-91.

Koob GF. Neurobiology of Opioid Addiction: Opponent Process, Hyperkatifeia, and Negative Reinforcement. Biol Psychiatry. 2020 Jan; 87(1):44-53. 
Kotler M, Cohen H, Segman R, Gritsenko I, Nemanov L, Lerer B, et al. Excess dopamine D4 receptor (D4DR) exon III seven repeat allele in opioid-dependent subjects. Mol Psychiatry. 1997 May;2(3):251-4.

Kranzler HR, Gelernter J, O’Malley S, Hernandez-Avila CA, Kaufman D. Association of alcohol or other drug dependence with alleles of the mu opioid receptor gene (OPRM1). Alcohol Clin Exp Res. 1998 Sep;22(6):1359-62.

Kranzler HR, Zhou H, Kember RL, Vickers Smith R, Justice AC, Damrauer S, et al. Genomewide association study of alcohol consumption and use disorder in 274,424 individuals from multiple populations. Nat Commun. 2019 Apr;10(1):1499.

Krebs MO, Sautel F, Bourdel MC, Sokoloff P, Schwartz JC, Olié JP, et al. Dopamine D3 receptor gene variants and substance abuse in schizophrenia. Mol Psychiatry. 1998 Jul;3(4): 337-41.

Kreek MJ, Bart G, Lilly C, LaForge KS, Nielsen DA. Pharmacogenetics and human molecular genetics of opiate and cocaine addictions and their treatments. Pharmacol Rev. 2005 Mar; 57(1):1-26.

Kreider RM, Lofquist DA. Adopted children and stepchildren: 2010, population characteristics. Washington: Department of Commerce; 2014. p. 38.

Lawford BR, Young RM, Noble EP, Sargent J, Rowell J, Shadforth S, et al. The D(2) dopamine receptor $\mathrm{A}(1)$ allele and opioid dependence: association with heroin use and response to methadone treatment. Am J Med Genet. 2000 Oct;96(5):592-8.

Leventhal AM, David SP, Brightman M, Strong D, McGeary JE, Brown RA, et al. Dopamine D4 receptor gene variation moderates the efficacy of bupropion for smoking cessation. Pharmacogenomics J. 2012 Feb;12(1):86-92.

Levran O, Londono D, O’Hara K, Randesi M, Rotrosen J, Casadonte P, et al. Heroin addiction in African Americans: a hypothesis-driven association study. Genes Brain Behav. 2009 Jul;8(5):531-40.

Li T, Liu X, Zhao J, Hu X, Ball DM, Loh W, et al. Allelic association analysis of the dopamine D2, D3, 5-HT2A, and GABA(A)gamma2 receptors and serotonin transporter genes with heroin abuse in Chinese subjects. Am J Med Genet. 2002 Apr;114(3):329-35.

Li T, Liu X, Zhu ZH, Zhao J, Hu X, Sham PC, et al. Association analysis of polymorphisms in the $\mu$ opioid gene and heroin abuse in Chinese subjects. Addict Biol. 2000 Apr;5(2):181-6.

Liu HC, Lin SK, Liu SK, Chen SL, Hu CJ, Chang JG, et al. DAT polymorphism and diverse clinical manifestations in methamphetamine abusers. Psychiatr Genet. 2004 Mar;14(1):337.

Liu QR, Drgon T, Johnson C, Walther D, Hess J, Uhl GR. Addiction molecular genetics: 639,401 SNP whole genome association identifies many "cell adhesion" genes. Am J Med Genet B Neuropsychiatr Genet. 2006 Dec; 141B(8):918-25.
Luo X, Kranzler HR, Zhao H, Gelernter J. Haplotypes at the OPRM1 locus are associated with susceptibility to substance dependence in European-Americans. Am J Med Genet B Neuropsychiatr Genet. 2003 Jul;120B(1):97-108.

Maller JB, McVean G, Byrnes J, Vukcevic D, Palin K, Su Z, et al.; Wellcome Trust Case Control Consortium. Bayesian refinement of association signals for 14 loci in 3 common diseases. Nat Genet. 2012 Dec;44(12):1294-301.

Maurano MT, Humbert R, Rynes E, Thurman RE, Haugen E, Wang H, et al. Systematic localization of common disease-associated variation in regulatory DNA. Science. 2012 Sep; 337(6099):1190-5

Mayer P, Rochlitz H, Rauch E, Rommelspacher $\mathrm{H}$, Hasse HE, Schmidt S, et al. Association between a delta opioid receptor gene polymorphism and heroin dependence in man. Neuroreport. 1997 Jul;8(11):2547-50.

Merikangas KR, Stolar M, Stevens DE, Goulet J, Preisig MA, Fenton B, et al. Familial transmission of substance use disorders. Arch Gen Psychiatry. 1998 Nov;55(11):973-9.

Midanik L. Familial alcoholism and problem drinking in a national drinking practices survey. Addict Behav. 1983;8(2):133-41.

Moriya Y, Hall FS, Sora I. The role of serotonin in the effects of pyschostimulant drugs: Behavioral studies of addiction- and abuse-related phenotypes in knockout mice. In: Hall FS, editor. Serotonin: Biosynthesis, regulation and health Implications. Hauppauge (NY): NOVA; 2013. pp. 189-210.

Morris SE, Cuthbert BN. Research Domain Criteria: cognitive systems, neural circuits, and dimensions of behavior. Dialogues Clin Neurosci. 2012 Mar;14(1):29-37.

Muskiewicz DE, Uhl GR, Hall FS. The Role of Cell Adhesion Molecule Genes Regulating Neuroplasticity in Addiction. Neural Plast. 2018 Feb;2018:9803764.

Noble EP. The D2 dopamine receptor gene: a review of association studies in alcoholism and phenotypes. Alcohol. 1998a Jul;16(1):33-45.

Noble EP. DRD2 gene and alcoholism. Science. 1998b Aug;281(5381):1287-8.

Noble EP, Blum K, Khalsa ME, Ritchie T, Montgomery A, Wood RC, et al. Allelic association of the D2 dopamine receptor gene with cocaine dependence. Drug Alcohol Depend. 1993 Oct;33(3):271-85.

Noble EP, Zhang X, Ritchie T, Lawford BR, Grosser SC, Young RM, et al. D2 dopamine receptor and $\mathrm{GABA}(\mathrm{A})$ receptor beta3 subunit genes and alcoholism. Psychiatry Res. 1998 Nov;81(2):133-47.

Paranjapye A, Ruffin M, Harris A, Corvol H. Genetic variation in CFTR and modifier loci may modulate cystic fibrosis disease severity. J Cyst Fibros. 2020 Mar;19 Suppl 1:S10-4.

Persico AM, Bird G, Gabbay FH, Uhl GR. D2 dopamine receptor gene TaqI A1 and B1 restriction fragment length polymorphisms: enhanced frequencies in psychostimulant-preferring polysubstance abusers. Biol Psychiatry. 1996 Oct;40(8):776-84.
Robbins TW, Ersche KD, Everitt BJ. Drug addiction and the memory systems of the brain. Ann N Y Acad Sci. 2008 Oct;1141(1141):121.

Saccone SF, Hinrichs AL, Saccone NL, Chase GA, Konvicka K, Madden PA, et al. Cholinergic nicotinic receptor genes implicated in a nicotine dependence association study targeting 348 candidate genes with 3713 SNPs. Hum Mol Genet. 2007 Jan;16(1):36-49.

Sander T, Harms H, Lesch KP, Dufeu P, Kuhn S, Hoehe M, et al. Association analysis of a regulatory variation of the serotonin transporter gene with severe alcohol dependence. Alcohol Clin Exp Res. 1997a Nov;21(8):1356-9.

Sander T, Harms H, Podschus J, Finckh U, Nickel B, Rolfs A, et al. Allelic association of a dopamine transporter gene polymorphism in alcohol dependence with withdrawal seizures or delirium. Biol Psychiatry. 1997b Feb;41(3): 299-304.

Schaid DJ, Chen W, Larson NB. From genomewide associations to candidate causal variants by statistical fine-mapping. Nat Rev Genet. 2018 Aug; 19(8):491-504.

Schaub MA, Boyle AP, Kundaje A, Batzoglou S, Snyder M. Linking disease associations with regulatory information in the human genome. Genome Res. 2012 Sep;22(9):1748-59.

Schuckit MA. Studies of populations at high risk for alcoholism. Psychiatr Dev. 1985;3(1):3163.

Schuckit MA. An overview of genetic influences in alcoholism. J Subst Abuse Treat. 2009 Jan; 36(1):S5-14.

Scofield MD, Heinsbroek JA, Gipson CD, Kupchik YM, Spencer S, Smith AC, et al. The Nucleus Accumbens: Mechanisms of Addiction across Drug Classes Reflect the Importance of Glutamate Homeostasis. Pharmacol Rev. 2016 Jul;68(3):816-71.

Sebastiani P, Timofeev N, Dworkis DA, Perls TT, Steinberg MH. Genome-wide association studies and the genetic dissection of complex traits. Am J Hematol. 2009 Aug;84(8):504-15.

Serý O, Vojtová V, Zvolský P. The association study of DRD2, ACE and AGT gene polymorphisms and metamphetamine dependence. Physiol Res. 2001;50(1):43-50.

Shi J, Hui L, Xu Y, Wang F, Huang W, Hu G. Sequence variations in the mu-opioid receptor gene (OPRM1) associated with human addiction to heroin. Hum Mutat. 2002 Apr;19(4): 459-60.

Shimada S, Kitayama S, Lin CL, Patel A, Nanthakumar E, Gregor P, et al. Cloning and expression of a cocaine-sensitive dopamine transporter complementary DNA. Science. 1991 Oct;254(5031):576-8.

Smelson D, Yu L, Buyske S, Gonzalez G, Tischfield J, Deutsch CK, et al. Genetic association of GABA-A receptor alpha-2 and mu opioid receptor with cocaine cue-reactivity: evidence for inhibitory synaptic neurotransmission involvement in cocaine dependence. Am J Addict. 2012 Sep-Oct;21(5): 411-5. 
Smith SS, O'Hara BF, Persico AM, Gorelick DA, Newlin DB, Vlahov D, et al. Genetic vulnerability to drug abuse. The D2 dopamine receptor Taq I B1 restriction fragment length polymorphism appears more frequently in polysubstance abusers. Arch Gen Psychiatry. 1992 Sep;49(9):723-7.

Sora I, Li BJ, Igari M, Hall FS, Ikeda K. Transgenic mice in the study of drug addiction and the effects of psychostimulant drugs. Ann N Y Acad Sci. 2010 Feb;1187:218-46.

Sora I, Takahashi N, Funada M, Ujike H, Revay RS, Donovan DM, et al. Opiate receptor knockout mice define mu receptor roles in endogenous nociceptive responses and morphine-induced analgesia. Proc Natl Acad Sci USA. 1997 Feb;94(4):1544-9.

Sora I, Wichems C, Takahashi N, Li XF, Zeng Z, Revay R, et al. Cocaine reward models: conditioned place preference can be established in dopamine- and in serotonin-transporter knockout mice. Proc Natl Acad Sci USA. 1998 Jun;95(13):7699-704.

Stickel F, Moreno C, Hampe J, Morgan MY. The genetics of alcohol dependence and alcoholrelated liver disease. J Hepatol. 2017 Jan; 66(1):195-211.

Szeto CY, Tang NL, Lee DT, Stadlin A. Association between $\mathrm{mu}$ opioid receptor gene polymorphisms and Chinese heroin addicts. Neuroreport. 2001 May;12(6):1103-6.

Takahashi N, Miner LL, Sora I, Ujike H, Revay RS, Kostic V, et al. VMAT2 knockout mice: heterozygotes display reduced amphetamineconditioned reward, enhanced amphetamine locomotion, and enhanced MPTP toxicity. Proc Natl Acad Sci USA. 1997 Sep;94(18): 9938-43.

Tan EC, Tan CH, Karupathivan U, Yap EP. Mu opioid receptor gene polymorphisms and heroin dependence in Asian populations. Neuroreport. 2003 Mar;14(4):569-72.

Tapper AR, McKinney SL, Nashmi R, Schwarz J, Deshpande P, Labarca C, et al. Nicotine activation of alpha $4^{*}$ receptors: sufficient for reward, tolerance, and sensitization. Science. 2004 Nov;306(5698):1029-32.

Thomsen M, Han DD, Gu HH, Caine SB. Lack of cocaine self-administration in mice expressing a cocaine-insensitive dopamine transporter. J Pharmacol Exp Ther. 2009 Oct; 331(1):204-11.

Thorpe HH, Talhat MA, Khokhar JY. High genes: genetic underpinnings of cannabis use phenotypes. Prog Neuropsychopharmacol Biol Psychiatry. 2021 Mar; 106:110164.

True WR, Heath AC, Scherrer JF, Xian H, Lin N, Eisen SA, et al. Interrelationship of genetic and environmental influences on conduct disorder and alcohol and marijuana dependence symptoms. Am J Med Genet. 1999 Aug; 88(4):391-7.

Tsai SJ, Cheng CY, Shu LR, Yang CY, Pan CW, Liou YJ, et al. No association for D2 and D4 dopamine receptor polymorphisms and methamphetamine abuse in Chinese males. Psychiatr Genet. 2002 Mar;12(1):29-33.
Tsuang MT, Bar JL, Harley RM, Lyons MJ. The Harvard Twin Study of Substance Abuse: what we have learned. Harv Rev Psychiatry. 2001 Nov-Dec;9(6):267-79.

Tsuang MT, Lyons MJ, Meyer JM, Doyle T, Eisen SA, Goldberg J, et al. Co-occurrence of abuse of different drugs in men: the role of drugspecific and shared vulnerabilities. Arch Gen Psychiatry. 1998 Nov;55(11):967-72.

Uhl GR. Molecular genetic underpinnings of human substance abuse vulnerability: likely contributions to understanding addiction as a mnemonic process. Neuropharmacology. 2004;47 Suppl 1:140-7.

Uhl GR, Drgon T, Johnson C, Fatusin OO, Liu QR, Contoreggi $\mathrm{C}$, et al. "Higher order" addiction molecular genetics: convergent data from genome-wide association in humans and mice. Biochem Pharmacol. 2008a Jan;75(1):98-111.

Uhl GR, Drgon T, Johnson C, Li CY, Contoreggi $\mathrm{C}$, Hess J, et al. Molecular genetics of addiction and related heritable phenotypes: genome-wide association approaches identify "connectivity constellation" and drug target genes with pleiotropic effects. Ann N Y Acad Sci. 2008b Oct;1141(1):318-81.

Uhl GR, Drgon T, Johnson C, Ramoni MF, Behm FM, Rose JE. Genome-wide association for smoking cessation success in a trial of precessation nicotine replacement. Mol Med. 2010 Nov-Dec;16(11-12):513-26.

Uhl GR, Drgon T, Liu QR, Johnson C, Walther D, Komiyama T, et al. Genome-wide association for methamphetamine dependence: convergent results from 2 samples. Arch Gen Psychiatry. 2008c Mar;65(3):345-55.

Uhl GR, Drgonova J, Hall FS. Curious cases: altered dose-response relationships in addiction genetics. Pharmacol Ther. 2014 Mar; 141(3):335-46.

Uhl GR, Elmer GI, Labuda MC, Pickens RW, editors. Genetic influences in drug abuse. New York: Raven Press; 1995.

Uhl GR, Liu QR, Drgon T, Johnson C, Walther D, Rose JE. Molecular genetics of nicotine dependence and abstinence: whole genome association using 520,000 SNPs. BMC Genet. 2007 Apr;8(1):10.

Uhl GR, Liu QR, Walther D. Polysubstance abuse association genome scanning provides evidence for polygenic inheritance of common alleles at loci including BDNF and ADH. Am J Hum Genet. 2001a Oct;69(4):568-68.

Uhl GR, Liu QR, Walther D, Hess J, Naiman D. Polysubstance abuse-vulnerability genes: genome scans for association, using 1,004 subjects and 1,494 single-nucleotide polymorphisms. Am J Hum Genet. 2001b Dec;69(6): 1290-300.

Uhl GR, Martinez MJ, Paik P, Sulima A, Bi GH, Iyer $\mathrm{MR}$, et al. Cocaine reward is reduced by decreased expression of receptor-type protein tyrosine phosphatase D (PTPRD) and by a novel PTPRD antagonist. Proc Natl Acad Sci USA. 2018 Nov;115(45):11597-602.

United Nations. Child adoptions: trends and policies. New York: United Nations; 2009. van Staaden MJ, Huber R. Crayfish learning: addiction and the ganglionic brain. Perspect Behav Sci. 2018 Nov;41(2):417-29.

Vandenbergh DJ, Rodriguez LA, Hivert E, Schiller JH, Villareal G, Pugh EW, et al. Long forms of the dopamine receptor (DRD4) gene VNTR are more prevalent in substance abusers: no interaction with functional alleles of the catechol-o-methyltransferase (COMT) gene. Am J Med Genet. 2000 Oct;96(5):67883.

Vandenbergh DJ, Rodriguez LA, Miller IT, Uhl GR, Lachman HM. High-activity catechol-Omethyltransferase allele is more prevalent in polysubstance abusers. Am J Med Genet. 1997 Jul;74(4):439-42.

Verhulst B, Neale MC, Kendler KS. The heritability of alcohol use disorders: a meta-analysis of twin and adoption studies. Psychol Med. 2015 Apr;45(5):1061-72.

Vink JM, Willemsen G, Boomsma DI. Heritability of smoking initiation and nicotine dependence. Behav Genet. 2005 Jul;35(4):397-406.

Visscher PM, Wray NR, Zhang Q, Sklar P, McCarthy MI, Brown MA, et al. 10 Years of GWAS Discovery: Biology, Function, and Translation. Am J Hum Genet. 2017 Jul; 101(1):5-22.

Wang JB, Imai Y, Eppler CM, Gregor P, Spivak CE, Uhl GR. mu opiate receptor: cDNA cloning and expression. Proc Natl Acad Sci USA. 1993 Nov;90(21):10230-4.

Weighill D, Tschaplinski TJ, Tuskan GA, Jacobson D. Data Integration in Poplar: 'Omics Layers and Integration Strategies. Front Genet. 2019 Sep; 10:874.

Winstanley EL, Stover AN. The Impact of the Opioid Epidemic on Children and Adolescents. Clin Ther. 2019 Sep;41(9):1655-62.

Wise RA, Robble MA. Dopamine and Addiction. Annu Rev Psychol. 2020 Jan;71(1):79-106.

Xu K, Liu XH, Nagarajan S, Gu XY, Goldman D. Relationship of the delta-opioid receptor gene to heroin abuse in a large Chinese case/control sample. Am J Med Genet. 2002 Jun; 110(1):45-50.

Xuei X, Dick D, Flury-Wetherill L, Tian HJ, Agrawal A, Bierut L, et al. Association of the kappa-opioid system with alcohol dependence. Mol Psychiatry. 2006 Nov;11(11): 1016-24.

Yuferov V, Fussell D, LaForge KS, Nielsen DA, Gordon D, Ho A, et al. Redefinition of the human kappa opioid receptor gene (OPRK1) structure and association of haplotypes with opiate addiction. Pharmacogenetics. 2004 Dec;14(12):793-804.

Zhang H, Kranzler HR, Yang BZ, Luo X, Gelernter J. The OPRD1 and OPRK1 loci in alcohol or drug dependence: OPRD1 variation modulates substance dependence risk. Mol Psychiatry. 2008 May;13(5):531-43.

Zimprich A, Kraus J, Wöltje M, Mayer P, Rauch E, Höllt V. An allelic variation in the human prodynorphin gene promoter alters stimulusinduced expression. J Neurochem. $2000 \mathrm{Feb}$; 74(2):472-7. 